\title{
Aneta Parkes*
}

\section{MARKETINGOWE PUBLIC RELATIONS}

Z a r y s t r e ś c i: Na wstępie zaprezentowana zostanie charakterystyka public relations w klasycznym ujęciu, tj. wykorzystywanego w celach informacyjnych. Następnie przedstawiona zostanie kategoria komunikowania stosowanego w celach perswazyjnych i zjawisko marketingowego public relations (MPR). Podkreślone zostaną również różnice pomiędzy public relations jako działalnością stricte informacyjną a jego marketingową wersją, wykorzystywaną m.in. w celu wywierania wpływu na konsumenta oraz różnice pomiędzy public relations i reklamą. W końcowej części opracowania zwrócona zostanie uwaga na wzrastającą rolę marketingowego public relations.

$\mathrm{S} \nmid$ o w a k l u c z o w e: public relations; marketingowe public relations

\section{WSTEPP}

Public relations w obecnym kształcie zaczęto strukturyzować i powszechnie wykorzystywać na początku XX w. jako odpowiedź na potrzebę informowania społeczeństwa. Tak więc z założenia public relations było działalnością informacyjną i tak ujmowane powinno być w klasycznym tego słowa znaczeniu, bez względu na to, czy aktywność ta wpływa pośrednio na zmianę opinii lub postaw. Dodatkowo, gdy przekazywana informacja pomaga w budowie wspólnoty np. komunikacyjnej, możemy mówić o public relations w ujęciu humanistycznym lub społecznym.

Kwestią dyskusyjną może być czysto informacyjny charakter ww. klasycznego public relations, choćby ze względy na grupy interesu zaintere-

* Adres do korespondencji: Aneta Parkes, Społeczna Akademia Nauk, ul. Sienkiewicza 9, 90-113 Łódź,e-mail: a.jakonis@live.com 
sowane propagowaniem tej działalności, których zasadniczym celem była poprawa relacji pomiędzy biznesem a społeczeństwem i wzrost społecznej akceptacji dla biznesu. Mając na względzie potrzebę uzyskania pozytywnego komunikatu zwrotnego od odbiorcy, nasuwa się pytanie, na ile wytwarzane przez nadawcę komunikaty przekazuję pełną i rzetelną informację, a na ile jedynie wybrane aspekty tej informacji. Jak również, na ile komunikat odgrywa rolę jedynie informacyjną, a nie np. - pośrednio - również perswazyjną. Niemniej jednak public relations w klasycznej postaci było odpowiedzią na postulat, że ,społeczeństwo należy informować” [Tworzydło, Olędzki, 2008], który to postulać jest wciąż podtrzymywany.

Public relations było również wykorzystywane w celach stricte perswazyjnych, np. również w starożytności, kiedy jeszcze nie funkcjonowała współczesna nazwa tej działalności. Z czasem też zaczęto wykorzystywać je coraz szerzej w obszarze współczesnego marketingu i utożsamiać marketingowe public relations z public relations jako takim. Istotne jest natomiast rozróżnianie działalności public relations w klasycznym - informacyjnym - wydaniu, od komunikatów, które mają wywołać określony i zamierzony efekt, czyli komunikatów perswazyjnych. Istotność ta wynika przede wszystkim z etycznego punktu widzenia, zarówno w odniesieniu do praktykowania public relations, jak i jego społecznej percepcji.

\section{DEFINICJE PUBLIC RELATIONS}

Jak wspomniano powyżej, działania, które współcześnie określane są mianem public relations, znane były już w starożytności. Przybierały one kształt np. manipulowania informacjami, zdobywania zaufania i poparcia społecznego czy budowania konsensusu. Rozwój ww. aktywności miał miejsce w epoce renesansu i w czasie rewolucji francuskiej. Natomiast public relations w obecnym kształcie rozwinął się w USA w XX w. [http://www.gmazurek.com/download/public/zajecia2.pdf]. Powstanie public relations w Stanach Zjednoczonych poprzedził m.in. XIX-wieczny rozwój techniki i mediów masowych oraz taniej prasy poszukującej sensacji. Za ojców współczesnego (amerykańskiego) public relations uważani są Ivy Ledbetter Lee i Edward L. Bernays [Tworzydło, Olędzki, 2008]. W Polsce zainteresowanie tym, jak np. organizacje postrzegane są przez zewnętrzne otoczenie i nadanie ekonomicznego znaczenia kategorii wizerunku, zaczęło wzrastać po przełomie ustrojowym $1989 \mathrm{r}$. [Cenker, 2000]. 
Public relations to $\mathrm{w}$ dosłownym thumaczeniu $\mathrm{z}$ języka angielskiego określenie: publiczne relacje. Odnosi się ono do działalności komunikacyjnej, której efektem są obopólnie korzystne relacje z publicznością. Są to relacje danej instytucji/organizacji/osoby z jej publicznością, odgrywającą rolę zarówno odbiorcy, jak i nadawcy komunikatów. Public relations jest to więc forma komunikacyjnej interakcji (wzajemnego oddziaływania) [por. Parkes, 2013], ,jest to, w najszerszym ujęciu, forma komunikowania społecznego". Prof. J. Olędzki definiuje public relations jako wyższą formę komunikowania społecznego, jako komunikację społeczną z otoczeniem instytucji. Komunikacja ta jest nie tylko przekazywaniem komunikatów, ale też tworzeniem wspólnoty „W trakcie i na skutek komunikowania” [Olędzki, 2006, s. 26]" [Parkes, 2013, s. 154-155]. Wyżej wymienione charakterystyki przypisywane są informacyjnemu ujęciu public relations. W ujęciu informacyjnym zakłada się konieczność przekazywania otoczeniu prawdziwej, pełnej i rzetelnej informacji, jak i uczciwy, ujmowany z perspektywy humanistycznej, społeczny dialog, dzięki któremu możemy budować i podtrzymywać relacje oparte na zaufaniu [Tworzydło, Olędzki, 2008].

Kolejnym podejściem w ujmowaniu public relations jest tzw. podejście zarządcze, odnoszące się głównie do funkcjonowania organizacji gospodarczych. W tym ujęciu public relations określane jest jako funkcja zarządzania, która ma za zadanie ocenę społecznego nastawienia wobec organizacji i jej produktów/usług i ustalenie zgodnego z interesem społecznym kierunku działania firmy. Efektem realizacji tak rozumianego public relations powinno być pozyskanie społecznego zrozumienia i akceptacji [Cenker 2000] oraz podtrzymywanie pozytywnej reputacji przedsiębiorstwa i wzajemnego zrozumienia pomiędzy instytucją a odbiorcami jej działań [Gregory, 2005, s. 12]. Np. definicja K. Wójcik wpisuje się w taką charakterystykę - public relations określane jest jako ,zarządzanie procesami komunikacyjnymi między organizacją i osobami a ich grupami odniesienia przez świadome, celowe i systematyczne kształtowanie tych procesów" [Wójcik, 1997, s. 16].

Jak widzimy na podstawie przytoczonych powyżej definicji, zarówno w informacyjnym, jak i zarządczym ujęciu komunikacja w public relations ma dwukierunkowy charakter. Jest to kluczowy element odróżniający je od propagandy, która jest komunikowaniem jednokierunkowym, czyli przekazywaniem komunikatów bez możliwości reakcji zwrotnej. Na skutek swojego jednokierunkowego komunikacyjnego charakteru, poprzez komunikowanie jednego punktu widzenia, propaganda jest wykorzystywana m.in. do 
wywieraniu wpływu na odbiorcę [por. Tworzydło, Olędzki, 2008]. Public relations to komunikowanie o charakterze dwukierunkowym, niemniej jednak również jest ono wykorzystywane - pośrednio lub bezpośrednio - do wywierania wpływu na odbiorcę. W odniesieniu do bezpośredniego wywierania wpływu rolę tę spełnia public relations w ujęciu marketingowym, charakteryzujące się perswazyjnym charakterem. Perswazja definiowana jest jako „namawianie do czegoś lub odradzanie czegoś z przytoczeniem odpowiednich argumentów" [http://sjp.pwn.pl/sjp/perswazja;2571293], czyli przekonywanie do swojego punktu widzenia. Perswazyjny charakter komunikatów charakteryzuje public relations w trzecim ujęciu, tj. marketingowym, gdzie jest ono określane nie tylko jako informowanie, ale i przekonywanie [Gregory, 2005, s. 12]. W odniesieniu do ujęcia marketingowego, public relations wykorzystywane jest do bezpośredniego przekonywania do danego punktu widzenia, np. w celu sfinalizowania sprzedaży lub też w celu budowy i podtrzymywania pożądanego wizerunku [Sznajder, 2000, s. 120], wspierającego sprzedaż.

\section{PUBLIC RELATIONS \\ W ASPEKCIE INFORMACYJNYM I PERSWAZYJNYM}

Należy rozdzielić społeczny i marketingowy aspekt public relations, zarówno ucząc tej dyscypliny, praktykując ją lub też dbając o jej własny wizerunek. Współczesne natężenie działań z zakresu marketingowego public relations powoduje, że MPR utożsamiany jest z public relations jako takim, podczas gdy MPR powinien być traktowany raczej jako jego komercyjna wersja. Klasyczne public relations, polegające na wymianie informacji, również może wywierać wpływ, ale nie powinno być wykorzystywane bezpośrednio w tym celu. Podczas gdy narzędzia marketingowego public relations służą stricte budowie marki i w efekcie - maksymalizacji sprzedaży.

Klasyczne public relations, tj. PR w aspekcie informacyjnym, możemy określić jako informację, która jest uczciwa i obiektywna, fachowa i kompetentna, szybka, przyjazna dla mediów i opinii publicznej, etyczna i odpowiedzialna" [Dobek-Ostrowska, 2007, s. 339]. Jest to obiektywnie poprawne rozumienie dyscypliny public relations i tak powinna być ona definiowana. W obiektywnym informacyjnym znaczeniu dyscypliny ,podstawą jest szybkie i rzetelne przekazywanie informacji, co do której należy zachować zasady bezstronności i odpowiedzialności" [Parkes, 2013, s. 155-156]. Rzetelność i obiektywizm przekazywanych informacji w dzia- 
łaniach public relations podkreślany jest również przez czołowych specjalistów z tej dziedziny i przez profesjonalne organizacje, zajmujące się wdrażaniem kodeksów etycznych dla tego zawodu [patrz: Parkes, 2013].

„Więcej kwestii problematycznych pojawia się przy definicjach public relations o charakterze perswazyjnym, gdzie nacisk położony jest np. na: korzyść dla nadawcy, zmianę postaw klientów czy uzyskanie ich akceptacji dla danej instytucji" [Dobek-Ostrowska, 2007, s. 339]. W tej sytuacji, szczególnie przy marketingowym ujmowaniu public relations, np. wspierającym sprzedaż, kwestie obiektywnej i rzetelnej informacji mogą stać się problematyczne. Nawet przy produktach czy usługach o wysokich jakościowo i cennych walorach, przy wysokim poziomie konkurencyjności i wielości oferowanych dóbr, wciąż pozostaje potrzeba wyróżnienia się na rynku, zwrócenia uwagi potencjalnego klienta i nakłonienia go do nabycia oferowanego dobra" [Parkes, 2013, s. 156]. To z kolei wiąże się nie tylko z koniecznością informowania - przekazywania rzetelnej i pełnej informacji, ale również z taką treścią i formą przekazu tej informacji, która w maksymalnym stopniu nakłoni potencjalnego konsumenta do nabycia oferowanego towaru. Tak więc, w obszarze marketingu, public relations może przyjmować charakter silnie i bezpośrednio perswazyjny, często oparty na mechanizmie wywierania wpływu społecznego [por. Cialdini, 2001]. $\mathrm{W}$ public relations $\mathrm{w}$ ujęciu marketingowym stosowany jest bowiem przekaz, w którym zawarte jest ukryte poparcie ze strony osoby trzeciej i który pełni funkcję zarówno informowania, jak i przekonywania [Gregory, 2005, s. 12; por. Parkes, 2013].

Jak wspomniano na wstępie, kwestią dyskusyjną jest wytworzenie komunikatu o czystej informacyjnej lub perswazyjnej postaci. Komunikat informacyjny wywiera wpływ na odbiorcę, perswazja natomiast zawiera w sobie element informacji. Sądzę, że komunikaty mają w przeważającej, jeśli nie w całkowitej mierze, charakter mieszany, ze zmienną procentową informacyjną i perswazyjną zawartością. Przykładowo, organizacje realizujące kampanie społeczne, nagłaśniające ważne społecznie problemy, nie tylko informują i propagują daną inicjatywę, ale i wywierają wpływ na społeczną percepcję danego zjawiska. Ich celem jest bowiem ,pozyskanie poparcia społecznego. Tu pojawia się kolejne zagadnienie, a mianowicie czy etyczne jest stosowanie komunikatów silnie oddziałujących na emocje odbiorcy dla tzw. szczytnego celu, czyli co tak naprawdę i czy w ogóle - jest w interesie odbiorcy komunikatu, czy wciąż jest to realizacja celu nadawcy? Jak twierdzą specjaliści: «można mieć oczywiście uzasadnione obawy, że tak prowadzone kampanie są bliższe działaniom propa- 
gandowym, co jednakże nie dezawuuje ich pozytywnego edukacyjnego znaczenia w kształtowaniu pożądanych społecznie zachowań i postaw, jeśli prowadzone są zgodnie z zasadami zawodowej etyki PR-owca» [Olędzki, 2006, s. 24]" [Parkes, 2013, s. 156-157].

\section{MARKETINGOWE PUBLIC RELATIONS - CHARAKTERYSTYKA}

Jak zostało wspomniane na wstępie, public relations jest coraz powszechniej wykorzystywane w działalności marketingowej. Uzasadnieniem rosnącego zainteresowania PR może być np. spadek zaufania do klasycznej reklamy i zastępowanie reklamy właśnie public relations. Związane może to być również z dostrzeganiem wielkiego potencjału PR w odniesieniu do „budowania świadomości i preferencji publiczności, a także pozycjonowania, repozycjonowania i obrony produktu na każdym rynku" [Dobek-Ostrowska, 2007, s. 332]. Poza tym „badania przeprowadzone w USA wykazały, że MPR jest bardzo skuteczny w tworzeniu świadomości u klientów i wiedzy o markach, zarówno nowych, jak i starych, w pozyskiwaniu poszczególnych segmentów publiczności, lokalnych społeczności, w docieraniu do grup społecznych, etnicznych etc. W efekcie MPR może przyczyniać się do osiągania celów stricte marketingowych. Przez wykorzystanie całej gamy narzędzi dostępnych pracownikom public relations buduje się świadomość marki instytucji, organizacji, przedsiębiorstwa, oferowanych przez nie produktów, a także osób lub idei" [Dobek-Ostrowska, 2007, s. 333].

Marketingowe public relations ma na celu wspieranie sprzedaży, tak więc jego charakter jest przede wszystkim perswazyjny. Perswazja polega tu na nakłonieniu konsumenta do dokonania danego wyboru, czy to na polu działalności organizacji gospodarczych, politycznych, czy też organizacji non profit etc. Perswazja nie wyklucza informacji, jednakże dążenie do realizacji sprzedaży może determinować charakter komunikatów w zależności od tego, które z nich lepiej przyczynią się do realizacji założonego celu. Marketingowo ujmowane public relations jest określane jako Marketingowe Public Relations (MPR) [Szymańska, 2005].

Marketingowe Public Relations (MPR) można przedstawić graficznie jako część wspólną marketingu i public relations. MPR jest również określane jako część zintegrowanej komunikacji marketingowej (lub zintegrowany marketingowy proces komunikacji), której celem jest budowa spójnego i wyraźnego przekazu odnośnie do organizacji i jej produktów 
[Szymańska, 2005]. Przykładem marketingowego narzędzia wykorzystywanego przez MPR jest np. system identyfikacji wizualnej (SIW). Jest on domeną marketingu i również częścią zintegrowanej komunikacji marketingowej [Szymańska, 2005].

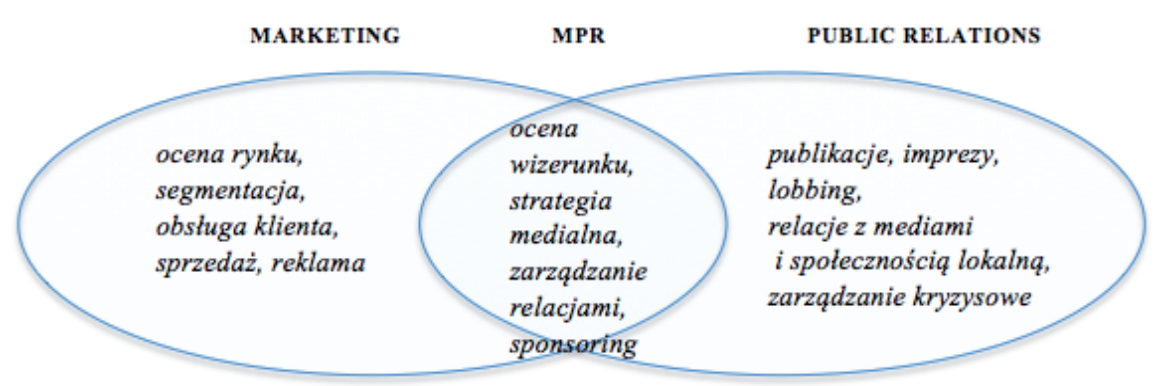

Rysunek 1. Przykłady działań w obszarze marketingu, marketingowego public relations i public relations

Źródło: https://lilwoggy.files.wordpress.com/2010/03/marketing-pr-diagram1.jpg [22.05.2015].

W marketingowym ujęciu public relations może być wykorzystywane do sterowania opinią publiczną w celu budowy pożądanego wizerunku lub wywołania popytu na produkt [patrz: Szymańska, 2005]. Jego celem nie jest tu więc bezpośrednio informowanie czy dialog z publicznością, ale wywarcie wpływu na jej opinie, postawy i zachowania [patrz: Parkes]. Wpływ ten może być wywierany np. poprzez kreowanie wizerunku firmy, ale i marki. „Analizy rynkowe jasno wskazują, że w warunkach ostrej konkurencji, o wielkości sprzedaży porównywalnych jakościowo i cenowo produktów, decyduje wizerunek organizacji i jej postrzeganie przez publiczność. $Z$ tego też powodu coraz większe znaczenie firmy przywiązują do tzw. społecznego zaangażowania biznesu. W profesjonalnie zarządzanych organizmach powołuje się specjalne grupy marketingowego public relations (MPR). Ich celem jest wzmocnienie strategii marketingowych przez promocję firmy i jej produktów oraz tworzenie i zarządzanie wizerunkiem tak, aby przełożyło się to na zwiększenie sprzedaży konkretnych towarów i usług" [Dobek-Ostrowska, 2007, s. 333].

MPR jest jednym z elementów marketingu mix, czyli tzw. koncepcji 4 x P, w skład której wchodzą następujące grupy zjawisk: product - produkt, price - cena, place - dystrybucja i promotion - promocja. Promocja obejmuje m.in. reklamę, public relations, promocję sprzedaży i sprzedaż 
bezpośrednią [por. Gregory, 2005, s. 11-12]. PR jest tu więc traktowane jako część działań promocyjnych [Parkes, 2013, s. 155]. Produkt (product) może obejmować takie kategorie, jak np.: asortyment, jakość, markę, cena (price) to np. rabaty czy warunki płatności, dystrybucja (place) to np. kanały lub zasięg terytorialny. Kiedy natomiast analizujemy promocję (promotion), wyróżniamy wśród niej takie formy, jak np. public relations, reklamę, sprzedaż bezpośrednią czy promocję sprzedaży [Kotler, 1994]. PR jest tu więc jednym z marketingowych narzędzi wspierających promocję.

Tabela 1. Cztery elementy marketingu mix -4 x P

\begin{tabular}{|c|c|c|c|}
\hline PRODUKT & CENA & PROMOCJA & $\begin{array}{c}\text { MIEJSCE } \\
\text { (DYSTRYBUCJA) }\end{array}$ \\
\hline $\begin{array}{l}\text { Asortyment } \\
\text { Jakość } \\
\text { Wzór } \\
\text { Cechy } \\
\text { Marka } \\
\text { Opakowanie } \\
\text { Rozmiary } \\
\text { Obsługa } \\
\text { Gwarancja }\end{array}$ & $\begin{array}{l}\text { Cena } \\
\text { Rabaty (zniżki) } \\
\text { Upusty } \\
\text { Warunki kredytowe } \\
\text { Terminy płatności } \\
\text { Strategie cenowe }\end{array}$ & $\begin{array}{l}\text { Reklama } \\
\text { Promocja sprzedaży } \\
\text { Public relations } \\
\text { Sprzedaż osobista } \\
\text { Marketing bezpośredni }\end{array}$ & $\begin{array}{l}\text { Sklepy } \\
\text { Kanały } \\
\text { Zasięg terytorialny } \\
\text { Oferowany asortyment } \\
\text { Transport } \\
\text { Poziom zapasów }\end{array}$ \\
\hline
\end{tabular}

Źródło: http://blogiceo.nq.pl/the-immortals/moduly-kursu/modul-3/ [20.05.2015]: na podstawie P. Kotler, Marketing, Gebethner i ska, Warszawa 1994.

Jak widzimy na przykładzie powyższej tabeli, zarówno public relations, jak i reklama stanowią narzędzia promocji. Występują jednak pomiędzy nimi istotne różnice. Najbardziej oczywistą jest to, kto jest nadawcą komunikatów reklamowych i komunikatów public relations. Przyjmuje się, że nadawcą w reklamie jest sam zainteresowany, tzn. ten, na kogo korzyść działa komunikat reklamowy. Podczas gdy nadawcą w działaniach public relations są inne opiniotwórcze podmioty. Wizualnie ww. różnice prezentuje poniższa ilustracja. Reklamą jest tu wydawania pozytywnej opinii o sobie samym, podczas gdy public relations to wydawanie pozytywnej opinii o nas przez inne podmioty. 


\section{Advertising vs. Public Relations}

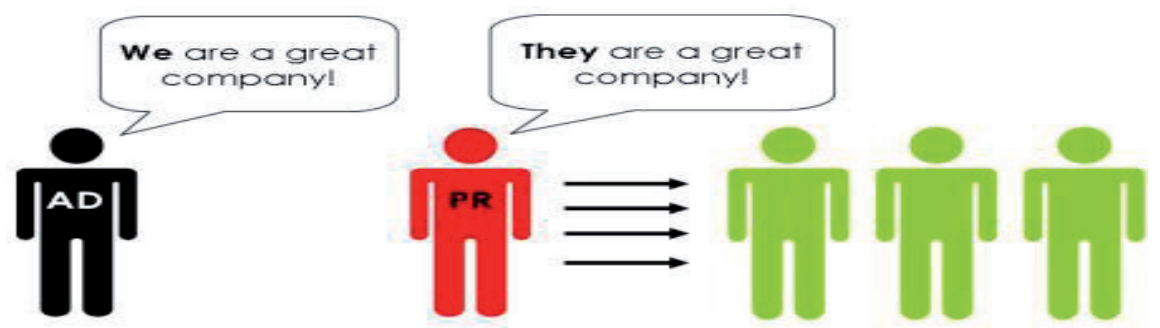

Rysunek 2. Graficzna reprezentacja różnicy pomiędzy reklamą a public relations

Źródło: https://amandawaymire.wordpress.com/marketing-concept/advertising-and-public-relations/ [22.05.2015]

Ponadto public relations różni się od reklamy tym, że za emisję przekazu reklamowego reklamodawca płaci bezpośrednio, decyduje, w jakim środku przekazu, jak często będzie nadawany i dyktuje treść komunikatu. PR może wpływać na wszystkie te elementy, jednak nie kieruje nimi bezpośrednio. Najczęściej posługuje się techniką press release, czyli przygotowaniem materiałów dla dziennikarzy, w których firma zwraca się do środków przekazu o umieszczenie danych informacji w komunikatach lub programach informacyjnych [por. Szymańska, 2005], techniką sponsoringu, współpracą z mediami, udziałem w targach i wystawach czy organizacją wydarzeń specjalnych [Cenker, 2000]. Np. tzw. sponsorowany artykuł reklamowy nie jest działalnością public relations, a jedynie płatnym dodatkiem reklamowym, który jest opłacony i zredagowany przez nadawcę i stanowi formę reklamy [patrz: Parkes]. Jak pisze D. Kaznowski w odniesieniu do środowiska Internetu, artykuły sponsorowane są tekstową formą reklamy. „Tekst dostarczany przez reklamodawcę jest zamieszczany w wybranym serwisie wśród zwykłych tekstów redakcyjnych. Zazwyczaj tytuły i linki tego typu wyróżniane są innym kolorem czcionki i wyraźnym napisem «reklama». Artykuły sponsorowane mają zastosowanie przy promocji złożonych produktów, które wymagają poza budowaniem świadomości produktu także dostarczenia bardziej szczegółowych informacji konsumentom" [Kaznowski, 2007, s. 145-146]. Artykuł sponsorowany bez oznaczeń wskazujących, że jest to reklama, bywa postrzegany jako pozorny public relations lub ukryta forma reklamy. Sam sponsoring natomiast, jak wspomniano powyżej, jest uznawany za narzędzie marketingowego public relations [Cenker, 2000]. 
Tabela 2. Różnice pomiędzy reklamą i public relations

\begin{tabular}{|l|l|}
\hline \multicolumn{1}{|c|}{ REKLAMA } & \multicolumn{1}{c|}{ PUBLIC RELATIONS } \\
\hline $\begin{array}{l}\text { za umieszczenie przekazu w mediach } \\
\text { zleceniodawca ponosi opłatę }\end{array}$ & $\begin{array}{l}\text { umieszczenie przekazu w mediach nie musi } \\
\text { (choć może) wiązać się z opłatą }\end{array}$ \\
\hline $\begin{array}{l}\text { zleceniodawca decyduje o treści i formie } \\
\text { komunikatu }\end{array}$ & $\begin{array}{l}\text { treści i forma komunikatu mogą (choć nie } \\
\text { muszą) zostać zmodyfikowane przez media }\end{array}$ \\
\hline przekaz jednokierunkowy & przekaz dwukierunkowy \\
\hline $\begin{array}{l}\text { istnieją produkty, których reklama jest } \\
\text { nieskuteczna lub zabroniona }\end{array}$ & $\begin{array}{l}\text { dowolność w promowaniu produktu, instytu- } \\
\text { cji, idei etc. }\end{array}$ \\
\hline to co organizacja/osoba mówi o sobie & to co inni mówią o organizacji/osobie \\
\hline
\end{tabular}

Źródło: opracowano na podstawie: https://www.akademiaparp.gov.pl/pigulka-wiedzy/414/reklama-a-public-relations-czym-sie-roznia [22.05.2015], B. Dobek-Ostrowska, (2007), Komunikowanie polityczne i publiczne, PWN, Warszawa, A. Gregory, (red.), (2005), Skuteczne techniki PR, Gdańskie Wydawnictwo Psychologiczne, Gdańsk.

Powyższa tabela prezentuje wybrane różnice pomiędzy działalnością public relations a reklamą. Pierwszą różnicą jest płatność za umieszczenie tekstu reklamowego w wybranym medium, gdzie przy reklamie stawki za umieszczenie i emisję są ściśle określone, podczas gdy umieszczenie informacyjnego przekazu nie musi wiązać się z dokonaniem opłaty. Reklamodawca decyduje również o formie i treści reklamy, podczas gdy informacja public relations przekazana np. dziennikarzowi może zostać przez niego użyta w zmienionej formie. Reklama jest przekazem jednokierunkowym, podczas gdy public relations zakłada dwukierunkowość przekazu, umożliwiającą podjęcie społecznego dialogu. W tym sensie reklama ma za zadanie wywrzeć bezpośredni wpływ na odbiorcę, podczas gdy public relations może, ale nie musi zakładać bezpośredniego oddziaływania. Oddziaływanie PR może mieć charakter bezpośredni, ale może też mieć charakter pośredni i skupiać się przede wszystkim na budowie relacji z klientami oraz pozyskiwaniu ich zaufania i lojalności, przyczyniając się tym do wspierania celów marketingowych. I, co istotne, public relations może być wykorzystywane w obszarach, gdzie reklama produktu jest nieskuteczna lub zabroniona/ograniczona, np. w odniesieniu do produktów alkoholowych.

Różnice pomiędzy reklamą a public relations ulegają niekiedy zatarciu, np. w medium Internetu. „Między reklamą internetową i e-marketingiem a e-PR jest cienka granica. PR internetowy nie wymaga jednak tak dużych 
nakładów finansowych od firm i bywa często o wiele skuteczniejszy" [Okonek, 2009, s. 9]. Działania firm przenoszone są w coraz większym stopniu na płaszczyznę internetową, ze względu na rosnące znaczenie i popularność tego środka przekazu. Internet, „o ile jeszcze kilka lat temu był uważany za medium niszowe, dziś jego pozycja umocniła się i zaczyna zagrażać pozycji tradycyjnych mediów, takich jak telewizja, prasa, radio czy kino. Zapewne w najbliższej przyszłości sieć nie zdominuje innych nośników informacji, ale niewątpliwie zmieni ich pozycję i kształt" [Kaznowski, 2007, s. 10]. Wzrost znaczenia Internetu wiąże się ze wzrostem jego popularności i dostępności, a co z tego wynika - przenoszeniem coraz większej ilości aktywności do jego obszaru. Jak piszą R. Laermer i M. Prichinello: „w naszej epoce światowej sieci możesz zaistnieć, jeśli dotrzesz ze swoją historią do ważnych witryn i magazynów internetowych. Wiele z nich zajmuje się prezentowaniem nowych spraw, a przeglądają je codziennie miliony ludzi. Ponadto łatwo jest się efektownie zaprezentować, korzystając z popularnych czatów, usług biuletynowych oraz posługując się innymi powszechnie stosowanymi metodami. Tradycyjne media na pewno zauważą, o czym ostatnio się pisze w sieci, i nagle może się okazać, że pojawiasz się na ekranie każdego komputera i niemal na każdej stronie internetowej" [Laermer, Prichinello, 2004, s. 13].

Zjawisko zacierania się granic pomiędzy reklamą a public relations, widoczne też w Internecie, wiąże się także z tym, że „Internet od początku był wykorzystywany do poszukiwania informacji, w tym także o produktach i usługach, jednak dotychczas wynikiem wyszukiwania była najczęściej witryna producenta lub dystrybutora" [Kaznowski, 2007, s. 13] - internetowa reklama w wyszukiwarkach. „W dobie serwisów społecznościowych i Web 2.0 sytuacja się zmieniła. Ilość, szybkość i jakość treści tworzonych przez internautów o produktach i markach sprawia, że coraz częściej konsumenci poszukujący informacji o produkcie najpierw trafiają na oceny i opinie o produkcie wyrażone przez innych użytkowników. Oznacza to dla firmy faktyczną utratę kontroli nad informacjami o produktach i usługach" [Kaznowski, 2007, s. 13]. Jak dalej pisze D. Kaznowski: „nie brak zwolenników teorii, że współtworzenie przez użytkowników treści i współdecydowanie o ich eksponowaniu jest naturalną drogą rozwoju internetu i mediów w ogóle. Zgodnie z tą teorią media masowe (tradycyjne) ewoluowały najpierw w stronę mediów spersonalizowanych, gdzie odbiorcy decydują o tym, co chcą otrzymywać, by następnie przerodzić się w Web 2.0 i decydować nie tylko o selekcji przekazu, ale także samodzielnie go tworzyć" [Kaznowski, 2007, s. 56]. Trudno jest jednak zweryfikować, czy treści 
umieszczone w serwisach lub blogach są wiarygodną i niezależną opinią użytkownika, czy reklamowym tekstem sponsorowanym. Tym bardziej że według wyników badania z 2007 r. wśród amerykańskich internautów „blogi coraz częściej wykorzystywane są też jako narzędzie marketingowe. Co ciekawe, jest to forma dosyć dobrze akceptowana przez internautów. 30 proc. czytelników blogów lubi czytać recenzje produktów i usług pisane przez zaufanych autorów blogów. 20 proc. nie ma nic przeciwko temu, by przekaz reklamowy był zawarty w treści bloga. Ponad 30 proc. internautów twierdzi też, iż prowadzenie bloga korporacyjnego prze firmę podnosi ich opinię o niej" [Kaznowski, 2007, s. 16]. Tak więc obecność samej reklamy w mediach społecznościowych wydaje się akceptowana. Kwestią dyskusyjną pozostaje wspomniana powyżej potencjalna trudność z rozróżnieniem, kiedy mamy do czynienia z reklamą, a kiedy z oryginalnym i wolnym głosem twórcy serwisu czy bloga.

\section{PODSUMOWANIE}

Odróżniając MPR od reklamy i klasycznego PR, należy zauważyć, że jest ono współcześnie powszechnie wykorzystywane nie tylko w odniesieniu do inicjatyw gospodarczych, ale też do działań politycznych (polityczne MPR) oraz społecznych (społeczne MPR). Np. w odniesieniu do produktów politycznych i politycznego public relations, ,które w systemach dojrzałej demokracji powinno przyjąć formę dialogu pomiędzy aktorami politycznymi a obywatelami, przynajmniej podczas komunikowania publicznego [patrz: Dobek-Ostrowska 2007]. Natomiast w procesie komunikowania politycznego (głównie podczas wyborów) bezpośrednim celem public relations jest wzmocnienie pozycji danego aktora politycznego i wygrana, trudno więc tu uniknąć stosowania technik wywierania wpływu społecznego w różnej postaci [patrz: Gancarz, 2009, s. 129]. O dialogu politycznym trudno też mówić w młodych, rozwijających się demokracjach z niewykształconym społeczeństwem obywatelskim, gdzie szczególnie podczas kampanii wyborczych celem nadrzędnym jest walka o władzę [Dobek-Ostrowska, 2007]. W takich sytuacjach, gdzie często pomijane jest opisane powyżej etyczne podejście humanistyczne [Olędzki, 2006, s. 17], można zadać pytanie o stosowanie np. zasady bezstronności w przekazywanych informacjach czy przestrzegania zasad kodeksów etycznych przez agencje public relations, szczególnie gdy podejmowane działania marketingowe nakierowane są na cel i maksymalizację korzyści” [Parkes 2013, s. 156]. Związane jest 
to również z traktowaniem polityki i polityków jako produktu i stosowania wobec nich tych samych zasad marketingowych, jakie wykorzystywane są w promocji towarów i usług. „Zasady marketingowego PR, stosowane w biznesie, zostały przełożone na potrzeby zbiorowych i indywidualnych aktorów politycznych, jak partie polityczne, instytucje władzy publicznej, przywódcy partyjni, prezydenci państw, szefowie rządów etc. W dojrzałych demokracjach, o wyższym poziomie profesjonalizacji komunikowania politycznego i kultury politycznej, podmioty polityki przywiązują dużą wagę do marketingowego public relations. Jego narzędzia wykorzystują nie tylko w okresie kampanii wyborczej, aby poprawić doraźną „,sprzedaż” swoich produktów (kandydatów w wyborach), ale wykazują dbałość o wizerunek w długim okresie między wyborami" [Dobek-Ostrowska, 2007, s. 334].

MPR jest też powszechnie praktykowane celem promowania niekomercyjnych inicjatyw społecznych. Przykładem są tu np. akcje marketingu społecznego, promującego przedsięwzięcia społecznie użyteczne. Marketing społeczny, nastawiony na zmianę społecznie szkodliwych zachowań i na „wspieranie celów społecznych w ramach marketingu komercyjnego" [Kowalska, Kowalski 2010, s. 72], może wykorzystywać techniki tzw. marketingu partyzanckiego (guerrilla marketing), charakteryzujący się niekonwencjonalnymi formami działalności marketingowej, mającymi przynieść maksymalne rezultaty przy minimalnych nakładach [Levinson, 1998]. Marketing partyzancki, wykorzystywany początkowo w kampaniach społecznych i małych przedsiębiorstwach bez zaplecza finansowego, jest obecnie powszechnie wykorzystywany również do promocji produktów zasobnych finansowo globalnych organizacji.

Jak widzimy na kilku powyższych przykładach, popularność marketingowego public relations obejmuje zarówno szerokie pole działania firm (biznesu), ale również wychodzi daleko poza obszar wspierania celów marketingowych szeroko rozumianego biznesu. Coraz częściej stosowane jest np. w promocji inicjatyw społecznych czy kampanii politycznych i spełnia funkcję wspierającą nie tylko sprzedaż towaru, usługi czy osoby, ale również coraz częściej - samej idei. 


\section{LITERATURA}

Cenker E. M., (2000), Public Relations, Wydawnictwo WSB, Poznań.

Cialdini R., (2001), Wywieranie wpływu na ludzi, Gdańskie Wydawnictwo Psychologiczne, Gdańsk.

Dobek-Ostrowska B., (2007), Komunikowanie polityczne i publiczne, PWN, Warszawa.

Gancarz B. (red.), (2009), Ten wredny PR 2009. Jak Public Relations zmienito Polskę, Helion, Gliwice.

Goban Klas T., (1997), Public relations czyli promocja reputacji, Business Press, Warszawa.

Gregory A. (red.), (2005), Skuteczne techniki PR, Gdańskie Wydawnictwo Psychologiczne, Gdańsk.

Kaznowski D., (2007), Nowy marketing w internecie, Difin, Warszawa.

Kotler P., (1994), Marketing, Gebethner \& S-ka, Warszawa.

Kowalska E., Kowalski M. (red.), (2010), Reklama w spoleczeństwie informacyjnym, Maternus Media, Tychy.

Laermer R., Prichinello M., (2004), Public Relations, Gdańskie Wydawnictwo Psychologiczne, Gdańsk.

Levinson J.C., (1998), Marketing partyzancki, PWE, Warszawa.

Okonek P., (2009), e-PR czyli jak skutecznie prowadzić PR $w$ sieci, PARP, Warszawa.

Olędzki J., (2006), Public relations w komunikacji społecznej [w:] T. Tworzydło, J. Olędzki (red.), Public Relations. Znaczenie spoteczne i kierunki rozwoju, PWN, Warszawa.

Parkes A., (2013), Public Relations - zagadnienia etyczne [w:] Ł. Sułkowski, G. Ignatowski (red.), Etyka w stużbie biznesu, Studia i Monografie nr 44, Wydawnictwo SAN.

Sternberg E., (1998), Czysty biznes. Etyka biznesu w działaniu, PWN, Warszawa.

Sznajder A., (2000), Marketing wirtualny, Oficyna Ekonomiczna, Dom Wydawniczy ABC, Kraków.

Szymańska A., (2005), PR w systemie zintegrowanej komunikacji marketingowej, UNIMEX, Wrocław.

Tworzydło D., Olędzki J., (2008), Public relations - biała czy czarna magia zarzadzania, PWN, Warszawa.

Wójcik K., (1997), Public Relations od A do Z, t. 1 i 2, Agencja Wydawnicza Placet. 
https://amandawaymire.wordpress.com/marketing-concept/advertising-and-public-relations/ [22.05.2015].

http://blogiceo.nq.pl/the-immortals/moduly-kursu/modul-3/ [20.05.2015].

https://lilwoggy.files.wordpress.com/2010/03/marketing-pr-diagram1.jpg [22.05.2015].

http://sjp.pwn.pl/sjp/perswazja;2571293 [22.05.2015].

https://www.akademiaparp.gov.pl/pigulka-wiedzy/414/reklama-a-public-relations-czym-sie-roznia [22.05.2015].

http://www.gmazurek.com/download/public/zajecia2.pdf [19.05.2015].

\section{MARKETING PUBLIC RELATIONS}

A b stra ct: At the outset, the characteristics of public relations in a classical sense, that is PR used for informational purposes, will be presented. Then, the category of communication used for persuasive purposes and marketing phenomenon of public relations (MPR) will be described. Furthermore, the differences between public relations considered as an informational activity and its marketing version, used in order to influence the consumer, as well as differences between public relations and an advertisement, will be highlighted. In the final part of the study, the attention will be returned to the increasing role of marketing public relations, not only in the business field, but also in the political and social campaigns.

K e y w o r d s: pubic relations; marketing public relations 